Research Paper

\title{
Toxigenic potential of Fusarium graminearum isolated from maize of northwest Argentina
}

\author{
D.A. Sampietro ${ }^{1}$, G.R. Apud ${ }^{1}$, M.M.E. Belizán ${ }^{1}$, M.A. Vattuone ${ }^{1}$, C.A.N. Catalán ${ }^{2}$ \\ ${ }^{1}$ LABIFITO, Facultad de Bioquímica, Química y Farmacia, Universidad Nacional de Tucumán, \\ San Miguel de Tucumán, Argentina. \\ ${ }^{2}$ INQUINOA-CONICET, Facultad de Bioquímica, Química y Farmacia, \\ Universidad Nacional de Tucumán, San Miguel de Tucumán, Argentina.
}

Submitted: February 3, 2012; Approved: July 23, 2012.

\begin{abstract}
Twenty six isolates of Fusarium graminearum from grains of maize hybrids harvested in \pm west Argentina were grown on autoclaved rice grain to assess their ability to produce type B trichothecenes. Chemical analysis indicated that $38 \%$ of isolates were nivalenol (NIV) producers only, $31 \%$ were major NIV producers with high DON(deoxynivalenol)/NIV ratios, $8 \%$ were major DON producers with minor NIV production, and $23 \%$ were DON producers only. Isolates showed a high variability in their toxigenic potential which was not related to fungal biomass. The distribution of the different chemotypes as well as the high and the low trichothecene-producing Fusarium isolates could not be associated to a geographical origin. Our results confirmed for the first time that isolates of Fusarium graminearum from maize of northwest Argentina are able to produce DON and NIV. A substancial contamination with both NIV and DON is likely in maize from northwest Argentina. Their contents should be quantified in regional surveillances for mycotoxin contamination.
\end{abstract}

Key words: Fusarium graminearum, trichothecenes, maize, chemotypes.

\section{Introduction}

Argentina is the second largest world exporter of maize in the world with about 4 million hectares sown in 2010 and 15 million tons harvested in 2011 (SAGPyA, 2011). In northwest Argentina, cultivation of maize has expanded rising 228,290 hectares and 1,300 tons during the last growing season. This expansion, however, is restricted by ear rot diseases including Gibberella ear rot caused by Fusarium graminearum (Schwabe) [teleomorph G. zeae (Schwein.) Petch]. Infection of cereal crops worldwide by this fungal pathogen significantly lowers grain yield and quality, and can result in the contamination of grain with type B-trichothecenes. These mycotoxins are a significant risk to food safety and animal health because they inhibit DNA, RNA and protein synthesis in eukaryotic cells (Pestka and Smolinski, 2005; Rocha et al., 2005; Ueno et al., 1973). In addition, trichothecenes can be acutely phyto- toxic and act as virulence factors on sensitive cereal hosts (Jansen et al., 2005).

Nivalenol (NIV) and deoxynivalenol (DON) are type B trichothecenes commonly found worldwide in cereals and their by-products (Desjardins, 2006). Isolates of $F$. graminearum usually have one of two chemotypes (11): (i) NIV chemotype: nivalenol and its acetylated derivatives, and (ii) DON chemotype: with production of either DON and 3ADON (chemotype IA) or DON and 15ADON (chemotype IB). DON is associated with feed refusal, vomiting and suppressed immune functions, and NIV is more toxic to humans and domestic animals than is DON (Ryu et al., 1988). Due to their differential toxicity, geographical distribution of these chemotypes defines the potential impact of type B trichothecenes on food safety (Reynoso et al., 2011). Only the DON chemotype has been found in cereals from United States and Canada (Miller et al., 1983), while both chemotypes were isolated in Japan (Yoshizawa and Jin, 1995), Italy (Logrieco et al., 1988), South Africa (Sy-

Send correspondence to D.A. Sampietro. Facultad de Bioquímica, Química y Farmacia, Universidad Nacional de Tucumán, España 2903 , 4000 San Miguel de Tucumán, Argentina.E-mail: dasampietro2006@yahoo.com.ar, dasampietro@hotmail.com. 
denham et al., 1991), and Australia (Blaney and Dodman, 1988). 2). The ability of Fusarium graminearum from Argentina to produce trichothecenes has been scarcely investigated and focused only on isolates collected from wheat (Alvarez et al., 2009; Faifer et al., 1990; Fernandez Pinto et al., 2008; Lori et al., 1992) and maize (Molto et al., 1997) from the center of the country. Ability of Fusarium graminearum to produce trichothecenes is controversial in Argentina with not already well defined chemotypes (Alvarez et al., 2009; Faifer et al., 1990; Fernandez Pinto et al., 2008; Lori et al., 1992; Molto et al., 1997) which are largely unknown in northwest Argentina. The purposes of this study were to determine: a) the pattern of type B trichothecenes produced by Fusarium graminearum isolated from maize of northwest Argentina, b) to evaluate whether there is a relationship between the type and the amount of toxin produced by these isolates and their geographical origin.

\section{Materials and Methods}

\section{Fungal isolates}

A collection of Fusarium were sampled from maize grains collected during 2010. Most samples were obtained from infected ears collected at different locations in the maize area of Tucumán province, in the center of northwest Argentina (Figure 1). Infected ears were harvested with a grain moisture of $20 \%$ and were obtained in 3 regions (South, East and North of Tucumán province) from northwest Argentina during the 2010 harvest season.

\section{Isolation and identification of Fusarium species}

Cereal grains from sampled ear were surface-sterilized for 1 min with a $5 \%$ sodium hypochlorite solution, rinsed twice in sterile distilled water and dried in a laminar flow cabinet. Then, grains were incubated in Potato Dex-

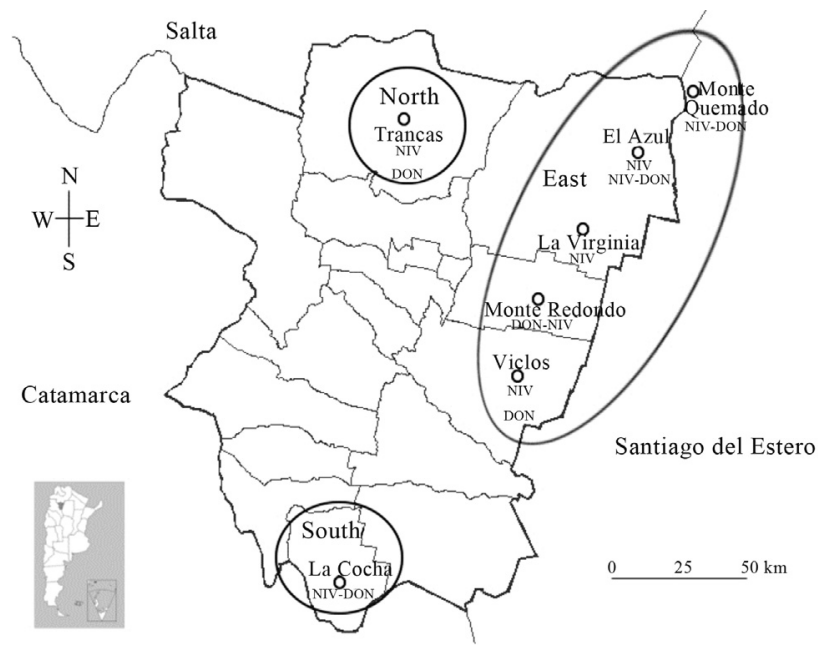

Figure 1 - Geographical locations of Fusarium graminearum isolated from maize ears in Northwest Argentina during 2010. trose Agar (PDA) at $28^{\circ} \mathrm{C}$ in the dark for $7 \mathrm{~d}$. All Fusarium isolates were subcultured on PDA and Spezieller Nahrstoffarmer Agar (SNA) using a single spore technique (Leslie and Summerell, 2006). PDA and SNA cultures were incubated at $25{ }^{\circ} \mathrm{C}$ for two to four weeks. Isolates were also grown in carnation leaf agar (CLA) according to Fisher et al. (1982). Cultural characters were assessed by eye and by microscopic examination. The morphology of macroconidia and chlamydospores was assessed from cultures grown on SNA and CLA. Morphological identifications of isolates were made using the criteria of Leslie and Summerell (2006). A total of 26 Fusarium isolates were recovered from the grain samples (Table 1).

Fungal isolates were also identified by a species specific PCR assay. DNA was extracted from fungal cultures. To do it, three mycelial disks were excised from the margin of a 3- to 5-d-old PDA plate cultures and crushed against the wall of a $1.5-\mathrm{ml}$ Eppendorf tube using a sterile pipette tip. DNA extraction was then carried out as previously described (Querol et al., 1992). The primer pair Fgr-F/Fgc-R based on IGS sequences was used for identification of Fusarium graminearum (Jurado et al., 2005; Sampietro et al. 2010). The thermal cycler conditions were: one cycle of $85 \mathrm{~s}$ at $94^{\circ} \mathrm{C}$, followed by 25 cycles of $30 \mathrm{~s}$ at $95^{\circ} \mathrm{C}$ (denaturation), $30 \mathrm{~s}$ at $53{ }^{\circ} \mathrm{C}$ (annealing), $30 \mathrm{~s}$ at $72{ }^{\circ} \mathrm{C}$ (extension), and one cycle of $5 \mathrm{~min}$ at $72{ }^{\circ} \mathrm{C}$. Amplification reactions were carried out in volumes of $25 \mu \mathrm{L}$ containing 200 ng of template DNA in $3 \mu \mathrm{L}, 1.25 \mu \mathrm{L}$ of each primer $(20 \mathrm{mM}), 0.2 \mu \mathrm{L}$ of $5 \mathrm{U} \mathrm{mL}^{-1}$ Taq DNA polymerase (Invitrogen), $2.5 \mathrm{~mL}$ of 10XPCR buffer $(20 \mathrm{mM}$ $\left(\mathrm{NH}_{4}\right)_{2} \mathrm{SO}_{4} ; 75 \mathrm{mM}$ Tris-HCl; $\left.50 \mathrm{mM} \mathrm{ClK} ; \mathrm{pH} 9\right), 1 \mu \mathrm{L}$ of $\mathrm{MgCl}_{2}(50 \mathrm{mM})$, and $0.25 \mu \mathrm{L}$ of dNTPs $(100 \mathrm{mM})$. PCR was performed in a thermocycler (Ivema T18, Ivema desarrollos SRL, Argentina). Amplification products were detected by electrophoresis on $1.5 \%$ agarose ethidium bromide gels in $40 \mathrm{mM}$ Tris-acetate and $1.0 \mathrm{mM}$ EDTA $1 \mathrm{x}$ buffer. The PCR assay included positive and negative controls containing a known amount of template DNA (i.e., from a standard strain) and a negative control without any addition of DNA. All the isolates are preserved in the LABIFITO culture collection as spore suspensions in 15\% glycerol frozen at $-80{ }^{\circ} \mathrm{C}$. Isolates of $F$. graminearum identified from wheat of center Argentina (Sampietro et al., 2010) were also included to check robutness of chemotype trichothecene analysis.

\section{Trichothecene chemotype determination}

Isolates of the Fg complex were cultured in Erlenmeyer flasks $(250 \mathrm{~mL})$ containing $25 \mathrm{~g}$ of long grain rice and $10 \mathrm{~mL}$ of distilled water. Flasks were autoclaved for $30 \mathrm{~min}$ at $121^{\circ} \mathrm{C}$, allowed to cool at room temperature for at least $24 \mathrm{~h}$, and then autoclaved a second time.

Then, each flask was inoculated with $1 \mathrm{~mL}$ of a $10^{5}$ macroconidia/mL suspension obtained from a ten-day-old fungal culture grown on Spezieller Nahrstoffarmer Agar 
Table 1 - Production of trichothecenes and ergosterol by Fusarium graminearum isolates on autoclaved rice grain.

\begin{tabular}{|c|c|c|c|c|c|c|c|c|}
\hline \multirow[t]{2}{*}{ Isolate ID } & & & \multicolumn{5}{|c|}{ Trichothecene content $(\mu \mathrm{g} / \mathrm{g} \text { dry rice medium })^{1}$} & \multirow{2}{*}{$\begin{array}{l}\text { Ergosterol content } \\
(\mu \mathrm{g} / \mathrm{g} \text { dry rice } \\
\text { medium })\end{array}$} \\
\hline & & & DON & NIV & $15 \mathrm{ADON}$ & 3ADON & $\begin{array}{l}\text { DON/NIV x } \\
100\end{array}$ & \\
\hline IQ1 & AX1013 MG & Viclos (east) & $\mathrm{ND}^{2}$ & $4.40 \pm 0.10 \mathrm{a}$ & ND & ND & - & $1100 \pm 2 \mathrm{a}$ \\
\hline IQ2 & AX1013 MG & Viclos (east) & ND & $2.1 \pm 0.14 \mathrm{~b}$ & ND & ND & - & $847 \pm 1 b$ \\
\hline IQ3 & NK135 TD MAX & Viclos (east) & ND & $1.40 \pm 0.10 \mathrm{~b}$ & ND & ND & - & $755 \pm 2 c$ \\
\hline IQ38 & AGROMEN 31A31 & Trancas (north) & ND & $1.20 \pm 0.11 \mathrm{~b}$ & ND & ND & - & $2145 \pm 4 \mathrm{a}$ \\
\hline IQ39 & AGROMEN 31A31 & Trancas (north) & ND & $1.80 \pm 0.09 \mathrm{~b}$ & ND & ND & - & $985 \pm 2 \mathrm{a}$ \\
\hline IQ15 & NK138 TD MAX & La Virginia (east) & ND & $1.50 \pm 0.14 \mathrm{~b}$ & ND & ND & - & $856 \pm 3 b$ \\
\hline IQ17 & NK138 TD MAX & Monte Redondo (east) & ND & $1.00 \pm 0.10 \mathrm{~b}$ & ND & ND & - & $879 \pm 3 b$ \\
\hline IQ18 & NK138 TD MAX & Monte Redondo (east) & ND & $1.70 \pm 0.12 b$ & ND & ND & - & $950 \pm 4 \mathrm{a}$ \\
\hline IQ62 & DK910 MG & El Azul (east) & ND & $19.70 \pm 0.50 \mathrm{c}$ & ND & ND & - & $867 \pm 1 b$ \\
\hline IQ64 & SPS 1104 & El Azul (east) & ND & $2.60 \pm 0.10 \mathrm{~b}$ & ND & ND & - & $1000 \pm 3 a$ \\
\hline IQ41 & AX1013 MG & Trancas (north) & $0.40 \pm 0.01$ & $2.40 \pm 0.15 b$ & ND & ND & 17 & $970 \pm 2 a$ \\
\hline IQ51 & NK138 TD MAX & El Azul (east) & $0.60 \pm 0.05$ & $7.10 \pm 0.13 \mathrm{~d}$ & ND & ND & 8 & $670 \pm 4$ \\
\hline IQ28 & MASG 34HX MG & La Cocha (south) & $0.30 \pm 0.01$ & $5.00 \pm 0.06 \mathrm{~d}$ & ND & ND & 6 & $890 \pm 2 b$ \\
\hline IQ58 & 2A $120 \mathrm{HX}$ & El Azul (east) & $0.50 \pm 0.01$ & $2.60 \pm 0.10 \mathrm{~b}$ & ND & ND & 19 & $934 \pm 3 a$ \\
\hline IQ77 & 2B 688 & Monte Quemado (east) & $11.40 \pm 1.10$ & $62.50 \pm 2.00 \mathrm{e}$ & ND & ND & 18 & $789 \pm 1 b$ \\
\hline IQ29 & NK135 TDMAX & La Cocha (south) & $2.1 \pm 0.30$ & $6.1 \pm 0.50 \mathrm{~d}$ & ND & ND & 34 & $687 \pm 3 c$ \\
\hline IQ34 & NK135 TDMAX & El Azul (east) & $1.7 \pm 0.20$ & $5.0 \pm 0.20 \mathrm{~d}$ & ND & ND & 34 & $940 \pm 1 \mathrm{a}$ \\
\hline IQ30 & NK135 TDMAX & La Cocha (south) & $0.3 \pm 0.10$ & $2.0 \pm 0.10 \mathrm{~b}$ & ND & ND & 15 & $1254 \pm 3 a$ \\
\hline IQ16 & AGRI 105 & Monte Redondo (east) & $34.80 \pm 1.30$ & $0.60 \pm 0.10 \mathrm{~b}$ & ND & ND & 5800 & $1987 \pm 2 \mathrm{a}$ \\
\hline IQ21 & AGRI 105 & Monte Redondo (east) & $26.10 \pm 0.10$ & $0.40 \pm 0.15 b$ & ND & ND & 6525 & $1200 \pm 4 a$ \\
\hline IQ10 & NK138 TD MAX & Viclos (east) & $39.70 \pm 1.50$ & ND & ND & ND & - & $978 \pm 1 \mathrm{a}$ \\
\hline IQ42 & D $390 \mathrm{MG}$ & Trancas (North) & $0.70 \pm 0.02$ & ND & ND & ND & - & $789 \pm 3 c$ \\
\hline IQ44 & DK910 MG & Trancas (North) & $2.5 \pm 0.10$ & ND & ND & ND & - & $679 \pm 2 c$ \\
\hline IQ45 & NK138 TD MAX & Trancas (North) & $3.2 \pm 0.08$ & ND & ND & ND & - & $980 \pm 1 \mathrm{a}$ \\
\hline IQ46 & NK138 TD MAX & Trancas (North) & $5.1 \pm 0.06$ & ND & ND & ND & - & $1112 \pm 3 a$ \\
\hline IQ82 & XTA8015 & Trancas (North) & $6.10 \pm 0.50$ & ND & ND & ND & - & $689 \pm 4 c$ \\
\hline IQ108 & Wheat $^{3}$ & $\begin{array}{l}\text { Pergamino (Buenos Ai- } \\
\text { res) }\end{array}$ & $118.4 \pm 4.00$ & ND & $1.0 \pm 0.30$ & ND & - & $879 \pm 5 b$ \\
\hline IQ109 & Wheat & $\begin{array}{l}\text { San Antonio de Areco } \\
\text { (Buenos Aires) }\end{array}$ & $120.1 \pm 3.00$ & ND & $1.2 \pm 0.20$ & ND & - & $1200 \pm 2 \mathrm{a}$ \\
\hline IQ110 & Wheat & $\begin{array}{l}9 \text { de Julio (Buenos Ai- } \\
\text { res) }\end{array}$ & $89.1 \pm 2.50$ & ND & $2.2 \pm 0.20$ & ND & - & $980 \pm 2 \mathrm{a}$ \\
\hline IQ111 & Wheat & Junín (Buenos Aires) & $94 \pm 3.50$ & ND & $1.8 \pm 0.10$ & ND & - & $780 \pm 3 b$ \\
\hline
\end{tabular}

${ }^{1}$ Trichothecenes produced in culture on rice grain. Results are provided as mean \pm standard deviation. Different letters into the same column indicate differences among means at 0.05 level (Tukey's test).

${ }^{2}$ Less than minimum level of detection $(<5 \mathrm{ng} / \mathrm{g}$ for each toxin).

${ }^{3}$ Wheat strains of $F$. graminearum with $15 \mathrm{ADON}$ chemotype obtained from wheat of center Argentina were included as control for chemical analysis.

(SNA) in a Petri dish at $25^{\circ} \mathrm{C}$ under continuous near UV light (Sampietro et al., 2010). Inoculated flasks were shaken by hand daily for 1 week to disperse the fungus throughout the rice. These cultures were incubated for 28 days at $25^{\circ} \mathrm{C}$ in dark. At the end of the incubation period, the contents of the flask were lyophilized and then stored at $-20{ }^{\circ} \mathrm{C}$ until analyzed for toxin. Each isolate was grown in triplicate.

Each dried sample was finely ground in a laboratory grinder and then homogenized. A sub-sample of ground rice $(15 \mathrm{~g})$ was extracted by mixing with $40 \mathrm{~mL}$ acetonitrile/water $(84: 16, \mathrm{v} / \mathrm{v})$, shaken for $1.5 \mathrm{~h}$ on an oscillatory 
shaker (150 rpm), and then filtered through Whatman No. 1 filter paper. The filtered extracts were pressed through MycoSep 230 NIV columns (Romer Labs Inc., Union, MO, U.S.A.) and $4 \mathrm{~mL}$ of the cleaned extract were evaporated to dryness. The residue was dissolved in $0.8 \mathrm{~mL}$ of acetonitrile/water (84:16, vol/vol), pressed through $0.45-\mu \mathrm{m}$ membrane filters. These filtered samples were in a binary gradient HPLC system using a GraceSmart C18 (25 mm x $4.7 \mathrm{~mm}, 5 \mu \mathrm{m}$ ) column at a flow rate of $0.5 \mathrm{~mL} / \mathrm{min}$ and detection at $220 \mathrm{~nm}$. Mobile phase was water acidified with $0.1 \%$ phosphoric (solvent A) and acetonitrile (solvent B). Gradient was as follows: 0\% B (1 min), an increase to $10 \%$ $\mathrm{B}$ (4 min), an increase to $25 \% \mathrm{~B}$ (45 min), and $40 \% \mathrm{~B}$ (10 $\mathrm{min})$.

Trichothecenes were quantified using external standards of deoxynivalenol, nivalenol and acetylated forms of deoxynivalenol (Sigma-Aldrich Co. St Louis,MO) injected at concentrations of 1 to $4 \mu \mathrm{g} \mathrm{mL}{ }^{-1}$ in acetonitrile/water (84:16). The quantification limit was $5 \mathrm{ng} / \mathrm{g}$ for each toxin.

\section{Ergosterol analysis}

Ergosterol concentration was assessed by HPLC in media inoculated with $F$. graminearum following Seitz et al. (1977), with some modifications. $15 \mathrm{~mL}$ of methanol and $1 \mathrm{~g}$ of lyophilized rice medium were mixed for $2 \mathrm{~min}$ in a $125 \mathrm{~mL}$ Erlenmeyer flask. The blend was poured into a $50 \mathrm{~mL}$ capped polypropylene centrifuge tube. The remaining blend from the erlenmeyer flask was washed off with $15 \mathrm{~mL}$ of methanol and poured into the centrifuge tube. The final extract was then centrifuged $15 \mathrm{~min}$ at 3,000 xg. The supernatant was poured off. The residue was re-suspended in $10 \mathrm{~mL}$ of methanol, shaken for $30 \mathrm{~s}$, and centrifuged as before. Supernatant portions were combined, mixed with $8.5 \mathrm{~g}$ of $\mathrm{KOH}$ and $25 \mathrm{~mL}$ of ethanol, and refluxed for $30 \mathrm{~min}$ at $65^{\circ} \mathrm{C}$. The cooled, saponified mixture was diluted with $5 \mathrm{~mL}$ of distilled water and extracted three times with $10 \mathrm{~mL}$ of hexane. Hexane extracts were combined and evaporated to dryness under reduced pressure at $35^{\circ} \mathrm{C}$. The dry residue was dissolved in $5 \mathrm{~mL}$ methanol (HPLC grade). The solution was transferred to vials for HPLC analysis after filtration through a $0.22 \mu \mathrm{m}$ PTFE membrane. Elution was performed at room temperature on the GraceSmart C18 (25 mm x $4.7 \mathrm{~mm}, 5 \mu \mathrm{m})$ column using methanol as mobile phase at a flow rate of $0.3 \mathrm{~mL} / \mathrm{min}$ and detection at $282 \mathrm{~nm}$. A volume of $20 \mu \mathrm{L}$ was injected into the HPLC. The ergosterol peak was eluted at about $6 \mathrm{~min}$. The quantification was made by external standardization (Ergosterol from Sigma, USA) with a calibration curve range from 1.0 to $15.0 \mu \mathrm{g} \mathrm{mL}^{-1}$. Analyses were performed in triplicate.

\section{Statistical analysis}

The data of chemical analysis were subjected to analysis of variance (ANOVA) with IBM SPSS statistics.
Means were compared using tukey's test at a significant level of $\alpha=0.05$.

\section{Results}

\section{Identity of fungal isolates}

The 26 fungal isolates collected from maize grains in northwest Argentina during 2010 were morphologically identified as belonging to Fusarium graminearum. Identity was confirmed by the PCR assay where a 500 bp single amplicon was obtained for each $F$. graminearum isolate as described by Jurado et al. (2005) and Sampietro et al. (2010).

\section{Chemical analysis of trichothecenes}

Chromatograms representative of the type B trichothecene chemotypes detected in the current work are shown in Figure 2. Four groups of isolates could be differentiated (Table 1): i) NIV producers: $38 \%$ of isolates accumulated NIV in a range of concentrations comprissed between 1 and $19.7 \mu \mathrm{g} / \mathrm{g}$ of dry rice medium. DON accumulation was not detected. ii) NIV and DON producers: $31 \%$ of isolates accumulated NIV in concentrations comprissed between 2 and $62 \mu \mathrm{g} / \mathrm{g}$ in dry rice medium with accumulation of

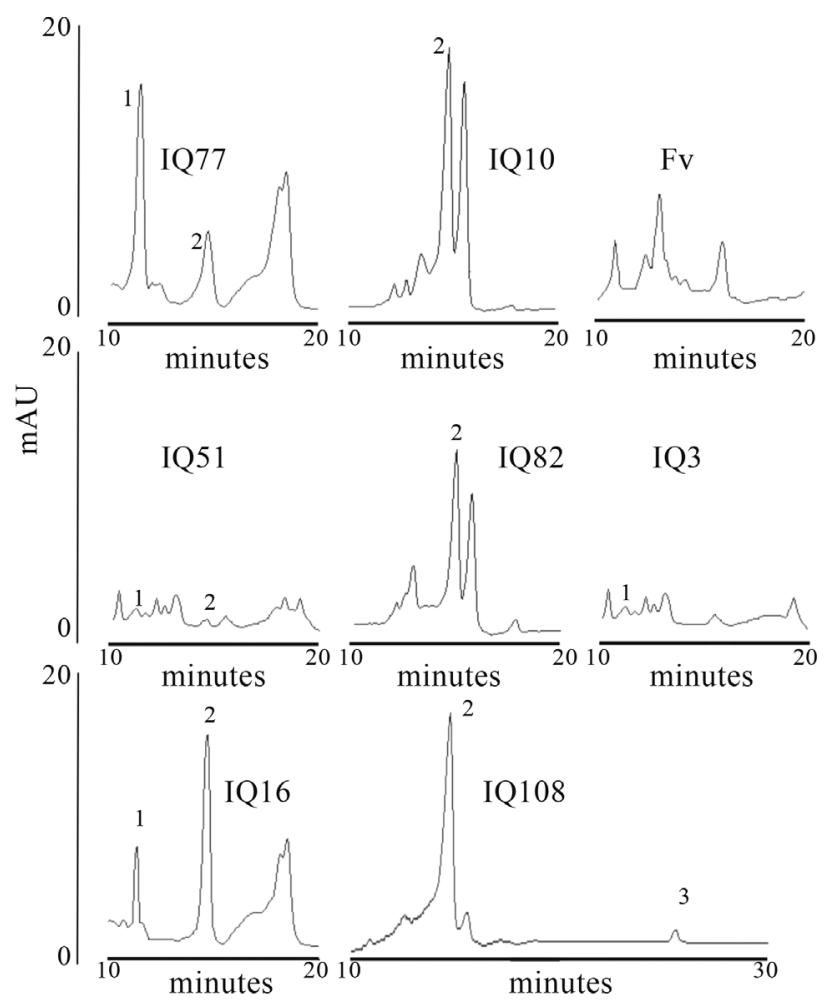

Figure 2 - Chromatograms representative of the type B trichothecene chemotypes detected in the tested isolates of $F$. graminearum. Absorbance of trichothecenes was detected at $220 \mathrm{~nm}$. Retention times are indicated for nivalenol (1), deoxynivalenol (2), and 15-acetyl-deoxynivalenol (3) were $11.9 ; 15.15$ and 25.7 min, respectively. Fv = Negative control was an isolate of Fusarium veticillioides (a non-trichothecene producer). 
6-34\% DON respect to NIV (percentage of DON calculated taking NIV concentration as base 100). iii) DON and NIV producers: $8 \%$ of isolates accumulated DON in concentrations comprissed between 34.8 y $26.1 \mu \mathrm{g} / \mathrm{g}$ of dry rice medium, with $1.5-1.6 \%$ of NIV respect to DON (percentage of NIV calculated taking DON concentration as base 100). iv) DON producers: $23 \%$ of isolates accumulated only DON in concentrations comprissed between 0.7 and $39.7 \mu \mathrm{g} / \mathrm{g}$ dry rice medium. Acetylated forms of DON were not detected in isolates of these four groups. In contrast, isolates of $F$. graminearum obtained from wheat of center Argentina accumulated mainly DON (89.1-120.1 $\mu \mathrm{g} / \mathrm{g}$ dry rice medium) with low content of $15 \mathrm{ADON}(1-2.2 \mu \mathrm{g} / \mathrm{g}$ dry rice medium).

\section{Ergosterol analysis}

The content of ergosterol, a metabolite reflecting fungal biomass, was comprissed between $670 \pm 4$ and $2145 \pm$ $4 \mu \mathrm{g} / \mathrm{g}$ dry rice medium and was not correlated to NIV or DON accumulation $\left(R^{2}=0.08\right.$ and $R^{2}=0.02$, respectively).

\section{Discussion}

The 26 fungal isolates collected in northwest Argentina were consistently identified as $F$. graminearum by both morphological and molecular criteria. The isolates were cultured in rice medium in order to detect qualitative and quantitative differences in trichothecene production among the isolates, as well as to check the relationship between trichothecene accumulation and fungal biomass. Chemical analysis indicated that from 26 isolates, 38\% had NIV chemotype, $23 \%$ had a DON chemotype although not the typical IB or IA as suggested by the absence of DON acetylated forms, and $39 \%$ of the isolates seemed to be a new NIV/DON chemotype with unexpected high levels of DON accumulation. Some isolates from Japan, Hungary and Nepal able to produce NIV and DON have been reported earlier (Desjardins and Plattner, 2009; Desjardins and Proctor, 2011; Szecsi et al., 2005). Our results seem to confirm the presence of unusual type B trichothecene chemotypes in $F$. graminearum from Argentina. Unexpected DON/NIV ratios also have been found on isolates of $F$. graminearum collected in wheat of center Argentina but with major DON production and $80-1500 \%$ DON respect to NIV (Dalcero et al., 1997; Fernandez Pinto et al., 2008). In a previous analysis of trichothecene production by Fusarium graminearum isolated from maize in Argentina, Molto et al. (1997) reported that all isolates produced DON. The 13 of 32 isolates collected in wheat of center Argentina were NIV producers mainly concentrated in the northern of Buenos Aires province (Fernandez Pinto et al., 2008), and the NIV chemotype was absent from recent surveys of Fusarium graminearum isolates collected from across the major wheat production area in Argentina (Alvarez et al., 2009; Reynoso et al., 2011). Levels of DON contamination in wheat grains of Ar- gentina seem to be higher as compared to NIV. These reports suggest that DON is most likely to appear as contaminant in freshly harvested maize and wheat of center Argentina, while our data suggest that a substancial contamination with both DON and NIV is possible in maize of northwest Argentina.

Quantities of trichothecenes accumulated by the fungal isolates were highly variable and independent of the production of fungal biomass. This variation in toxigenic potential among isolates might explain the wide range of trichothecene contents previously detected in cereal samples from Argentina (Alvarez et al., 2009; Reynoso et al., 2011). As reported for other Fusarium species that also are trichothecene producers (Bakan et al., 2001), toxigenic potential of isolates could not be associated to geographical origin or with maize hybrid.

\section{Conclusions}

Our results indicate a highly variable toxigenic potential of Fusarium graminearum in northwest Argentina. Dominance of the NIV chemotype among isolates collected from maize is of significant concern to food safety and animal production because of the greater toxic potential of NIV relative to DON. Unusual trichothecene chemotypes were identified with unexpected enhanced DON production. Maize grain from northwest Argentina could be naturally contaminated with both DON and NIV, and further studies will be focus to assess the real impact of the Fusarium graminearum in regional contamination of maize grains.

\section{Acknowledgments}

This work has been partially supported by grants from CONICET and SECyT (Argentina).

\section{References}

Alvarez CL, Azcarate MP, Fernández Pinto V (2009) Toxigenic potential of Fusarium graminearum sensu stricto isolates from wheat in Argentina. International Journal of Food Microbiology 135:131-135.

Bakan B, Pinson L, Cahagnier B, Melcion D, Sémon E, Richard-Molard D (2001) Toxigenic potential of Fusarium culmorum strains isolated from French wheat. Food Additives and Contaminants 18:998-1003.

Blaney BJ, Dodman RL (1988) Production of the mycotoxins zearalenone, deoxynivalenol and nivalenol by isolates of Fusarium graminearum Groups 1 and 2 from cereals in Queensland. Australian Journal of Agricultural Research 39:21-29.

Dalcero A, Torres A, Etcheverry M, Chulze S, Varsavsky E (1997) Occurrence of deoxynivalenol and Fusarium graminearum in Argentinian wheat. Food Additives and Contaminants 14:11-14.

Desjardins AE (2006) Fusarium Mycotoxins: Chemistry, Genetics, and Biology. APS Press, St. Paul. 
Desjardins AE, Plattner RD (2003) Diverse traits for pathogen fitness in Gibberella zeae. Canadian Journal of Plant Pathology 25:21-27.

Desjardins AE, Proctor RH (2011) Genetic diversity and trichothecene chemotypes of the Fusarium graminearum clade isolated from maize in Nepal and identification of a putative new lineage. Fungal Biology 115:38-48.

Faifer GC, de Sala Miguel M, Godoy HM (1990) Patterns of mycotoxin production by Fusarium graminearum isolated from Argentina wheat. Mycopathologia 109:165-170.

Fisher NL, Burgess LW, Toussoun TA, Nelson PE (1982) Carnation leaves as a suitable substrate and for preserving cultures of Fusarium. Phytopathology 72:151-153.

Fernandez Pinto VE, Terminello LA, Basilico JC, Ritieni A (2008) Natural occurrence of nivalenol and mycotoxicogenic potential of Fusarium graminearum strains in wheat affected by head blight in Argentina. Brazilian Journal of Microbiology 39:157-162.

Ichinoe M, Kurata H, Sugiura Y, Ueno Y (1983) Chemotaxonomy of Gibberella zeae with special reference to production of trichothecenes and zearalenone. Applied and Environmental Microbiology 46:1364-1369.

Jansen C, von Wettstein D, Schafer W, Kogel KH, Felk A, Maier FJ (2005) Infection patterns in barley and wheat spikes inoculated with wild-type and trichodiene synthase gene disrupted Fusarium graminearum. Proceedings of the National Academy of Sciences of the United States of America 102:16892-16897.

Jurado M, Vazquez C, Patiño B, Gonzalez Jaen MT (2005) PCR detection assays for the trichothecene-producing species Fusarium graminearum, Fusarium culmorum, Fusarium poae, Fusarium equiseti and Fusarium sporotrichioides. Systematic and Applied Microbiology 28:562-568.

Leslie JF, Summerell BA (2006) The Fusarium Laboratory Manual. Blackwell Publishing Professional, Ames.

Logrieco A, Bottalico A, Altomare C (1988) Chemotaxonomic observations on zearalenone and trichothecene production by Gibberella zeae from cereals in southern Italy. Mycologia 80:892-895.

Lori GA, Carranza MR, Violante A, Rizzo I, Alippi HE (1992) Fusarium spp en trigo, capacidad toxicogenica y quimiotaxonomìa de las cepas aisladas en la Argentina. Agronomie 12:459-467.

Miller JD, Taylor A, Greenhalgh R (1983) Production of deoxynivalenol and related compounds in liquid culture by Fusarium graminearum. Canadian Journal Microbiology 29:1171-1178.

Molto GA. Gonzalez HH, Resnik SL, Pereyra Gonzalez A (1997) Production of trichothecenes and zearalenone by isolates of Fusarium spp. from Argentinian maize. Food Additives and Contaminants 14:263-268.
Pestka JJ, Smolinski AT (2005) Deoxynivalenol: Toxicology and potential effects onhumans. Journal of Toxicology and Environmental Health. Part B: Critical Reviews 8:39-69.

Querol A, Barrio E, Huerta T, Ramon D (1992) Molecular monitoring of wine fermentations conducted by active dry yeast strains. Applied Environmental Microbiology 58:29482953.

Reynoso MM, Ramirez ML, Torres AM, Chulze SN (2011) Trichothecene genotypes and chemotypes in Fusarium graminearum strains isolated from wheat in Argentina. International Journal of Food Microbiology 145:444-448.

Rocha O, Ansari K, Doohan FM (2005) Effects of trichothecene mycotoxins on eukaryotic cells: A review. Food Additives and Contaminants 22:369-378.

Ryu JC, Ohtsubo K, Izumiyama N, Nakamura K, Tanaka T, Yamamura H, Ueno Y (1988) The acute and chronic toxicities of nivalenol in mice. Fundamental and Applied Toxicology 11:38-47.

Sampietro DA, Marín P, Iglesias J, Presello DA, Vattuone MA, Catalan CAN, Gonzalez Jaen MT (2010) A molecular based strategy for rapid diagnosis of toxigenic Fusarium species associated to cereal grains from Argentina. Fungal Biology 114:74-81.

Secretarya de Agricultura, Ganaderya, Pesca y Alimentos (SAGPyA) (Secretary of Agriculture, Livestock, Fisheries and Food), Instituto Interamericano de Cooperacio n para la Agricultura (IICA) (Institute for Interamerican Agricultural Cooperation), 2011. Perspectivas de los biocombustibles en la Argentina y en Brazil (Perspectives of liquid biofuels in Argentina and Brazil). URL: /http://www.sagpya.mecon.gov.ar/ (accessed 1-12-2011).

Seitz LM, Mohr HE, Burroughs R, Sauer B (1977) Ergosterol as an indicator of fungal invasion in grains. Cereal Chemistry 54:1207-1217.

Sydenham EW, Marasas WFO, Thiel PG, Shephard GS, Nieuwenhuis JJ (1991) Production of mycotoxins by selected Fusarium graminearum and F. crookwellense isolates. Food Additives and Contaminants 8:31-41.

Szecsi A, Bartok T, Varga M, Magyar D, Mesterhazy A (2005) Determination of trichothecene chemotypes of Fusarium graminearum strains isolated in Hungary. Journal of Phytopathology 153:445-448.

Ueno Y, Nakajima M, Sakai K, Ishii K, Sato N, Shimada N (1973) Comparative toxicology of trichothecene mycotoxins: Inhibition of protein synthesis in animal cells. Journal of Biochemistry (Tokyo) 74:285-296.

Yoshizawa T, Jin YZ (1995) Natural occurrence of acetylated derivatives of deoxynivalenol and nivalenol in wheat and barley in Japan. Food Additives and Contaminants 12:689-694.

All the content of the journal, except where otherwise noted, is licensed under a Creative Commons License CC BY-NC. 